\title{
Curcumin Ameliorates Benzo[a]pyrene-Induced DNA Damages in Stomach Tissues of Sprague-Dawley Rats
}

\author{
Kyeong Seok Kim ${ }^{1}$, Na Yoon Kim ${ }^{2}$, Ji Yeon Son ${ }^{1}$, Jae Hyeon Park ${ }^{1}$, Su Hyun Lee ${ }^{1}$, \\ Hae Ri Kim ${ }^{1}$, Boomin Kim ${ }^{1}$, Yoon Gyoon Kim ${ }^{2}$, Hye Gwang Jeong ${ }^{3}{ }^{\mathbb{D}}$, Byung Mu Lee ${ }^{1}$ and \\ Hyung Sik Kim ${ }^{1, *(1)}$ \\ 1 School of Pharmacy, Sungkyunkwan University, Gyeonggi-do, 2066, Seobu-ro, Suwon 16419, Korea; \\ caion123@nate.com (K.S.K.); twiase@naver.com (J.Y.S.); sky3640@naver.com (J.H.P.); \\ lydia7334@skku.edu (S.H.L.); kimhaeri56@daum.net (H.R.K.); boomin@hanmail.net (B.K.); \\ bmlee@skku.edu (B.M.L.) \\ 2 College of Pharmacy, Dankook University, Chungnam, 119, Cheonan 31116, Korea; \\ hjly226@hanmail.net (N.Y.K.); kyg90@dankook.ac.kr (Y.G.K.) \\ 3 College of Pharmacy, Chungnam National University, 99, Daehak-ro, Yuseong-gu, Daejeon 34134, Korea; \\ hgjeong@cnu.ac.kr \\ * Correspondence: hkims@skku.edu; Tel.: +82-312-907-789; Fax: +82-312-928-800
}

Received: 20 September 2019; Accepted: 29 October 2019; Published: 6 November 2019

check for updates

\begin{abstract}
Benzo[a]pyrene $(\mathrm{BaP})$ is a well-known carcinogen formed during the cooking process. Although $\mathrm{BaP}$ exposure has been implicated as one of the risk factors for lung cancer in animals and humans, there are only limited data on BaP-induced gastrointestinal cancer. Therefore, this study investigated the protective effects of curcumin on $\mathrm{BaP}$-induced DNA damage in rat stomach tissues. $\mathrm{BaP}(20 \mathrm{mg} / \mathrm{kg} / \mathrm{day})$ and curcumin $(50,100$, or $200 \mathrm{mg} / \mathrm{kg}$ ) were administered daily to Sprague-Dawley rats by oral gavage over 30 days. Curcumin was pre-administered before $\mathrm{BaP}$ exposure. All rats were euthanized, and liver, kidney, and stomach tissues were removed at $24 \mathrm{~h}$ after the last treatment. We observed that aspartate aminotransferase (AST), alanine aminotransferase (ALT), and glucose levels were significantly reduced in rats treated with high dose co-administration of curcumin (200 mg/kg) compared to BaP alone. The expression levels of cytochrome P450 (CYP) 1A1 and CYP1B1 were significantly increased in the liver of rats treated with BaP. However, co-administration of curcumin $(200 \mathrm{mg} / \mathrm{kg})$ with BaP markedly reduced CYP1A1 expression in a dose-dependent manner. Furthermore, plasma levels of BaP-diolepoxide (BPDE) and BaP metabolites were significantly reduced by co-administration of curcumin $(200 \mathrm{mg} / \mathrm{kg})$. Additionally, co-administration of curcumin (200 mg/kg) with BaP significantly reduced the formation of BPDE-I-DNA and 8-hydroxydeoxy guanosine (8-OHdG) adducts in the liver, kidney, and stomach tissues. The inhibition of these adduct formations were more prominent in the stomach tissues than in the liver. Overall, our observations suggest that curcumin might inhibit $\mathrm{BaP}$-induced gastrointestinal tumorigenesis and shows promise as a chemopreventive agent.
\end{abstract}

Keywords: curcumin; benzo(a)pyrene; gastrointestinal cancer; BPDE-I-DNA adduct; 8-hydroxydeoxy guanosine

\section{Introduction}

Benzo[a]pyrene $(\mathrm{BaP})$ is considered a major pollutant in the environment. $\mathrm{BaP}$ is a polyaromatic hydrocarbon (PAH) found in coal tar, coal-processing waste products, petroleum sludge, asphalt, and tobacco smoke [1,2]. Exposure to BaP causes various adverse health effects including cancer development, immunosuppression, teratogenicity, and hormonal dysfunctions [3,4]. With the exception 
of occupational exposure, the major route of BaP exposure to human is via contaminated foods because $\mathrm{BaP}$ can be produced by the pyrolysis of amino acids, fatty acids, and carbohydrates during the cooking process $[5,6]$. Therefore, the probability of BaP exposure to humans through the consumption of grilled meats, water, and smoked fishes is very high $[7,8]$. In addition to specific components of the diet, the cooking process is also associated with increased risk of gastrointestinal cancer, which is causatively related to the formation of BaP-DNA adducts in the stomach [9-11]. Furthermore, dietary habits have been linked to high incidence of gastric cancer in many areas of the world [12,13]. Previous studies indicated that $\mathrm{BaP}$ has been proven to cause cancer in the skin, lung, mammary glands, and forestomach tissues of experimental animals [14-16]. Although the molecular mechanism of BaP-induced gastric cancer has been elucidated, many studies have only indirectly evaluated the correlation between $\mathrm{BaP}$ exposure and gastric cancer. Therefore, the association remains unclear.

Gastric cancer is the fourth most common type of cancer and the second leading cause of cancer death in the world [17]. It is a major cause of cancer mortality in Korea, Japan, and India. The development of gastric cancer is a complex, multistep process involving multiple genetic and epigenetic alterations in oncogenes, tumor suppressor genes, DNA repair genes, cell cycle regulators, and signaling molecules $[18,19]$. At the early stage of gastric cancer, atrophy and intestinal metaplasia might be involved in the development of gastric adenocarcinoma [20]. The fact that diet also plays an important role in the etiology of gastric cancer offers a scope for nutritional chemoprevention. The development of multitargeted preventive and therapeutic strategies for gastric cancer is a major challenge for the future. Fruits, vegetables, common beverages, and several medicinal herbs with diversified pharmacological properties have been shown to be a rich source of cancer chemopreventive agents [21].

Curcumin (diferuloylmethane), a polyphenol compound, is an active ingredient of turmeric (Curcuma longa). Curcumin is a polyphenol of interest for application as a chemopreventive agent. The chemopreventive potential of curcumin in preventing the process of carcinogenesis was previously demonstrated by various studies [22-24]. Curcumin shows beneficial effects in many cancers including forestomach, colorectal cancer, breast cancer, skin cancer, and oral cancer [25-28]. Furthermore, curcumin has been known to retard the formation of DNA adducts by carcinogen exposure, and thus delay the process of tumorigenesis in several animal models $[29,30]$. However, data on the effect of curcumin on DNA adduct formation through the in vivo study of gastric cancer are limited. Therefore, the aim of the present study was to determine the protective effect of curcumin on BaP-induced gastric carcinogenesis.

\section{Results}

\subsection{Changes in Body Weight, Organ Weights, and Blood Biochemistry}

Over the experimental period, all animals were weighed periodically. Animals treated with either $\mathrm{BaP}$ or $\mathrm{BaP}$ in combination with curcumin exhibited a slight, but significant reduction in body weight compared to controls. However, there was no difference among the treated groups (Figure 1).

Liver weight was significantly reduced by the co-administration of BaP with curcumin (Table 1). Serum alanine aminotransferase (ALT) and aspartate aminotransferase (AST) activities, as well as blood urea nitrogen (BUN) and glucose levels, were significantly increased in the BaP-treated group compared with control group. In contrast, co-administration of curcumin (100 or $200 \mathrm{mg} / \mathrm{kg})$ with BaP exhibited significant reduction in AST, ALT, BUN, and glucose (Table 2). These results were highly correlated with the liver and kidney histopathological changes, whereby oral administration of BaP slightly increased hepatic and renal damage in rats. As shown in Figure 2, hepatic tissues displayed cell infiltration, mononuclear cells, and multifocal cells in rats. The induction in non-carcinogenic target tissues kidney showed only focal nephropathy (Table 3). We did not detect histopathological changes in the stomach. 


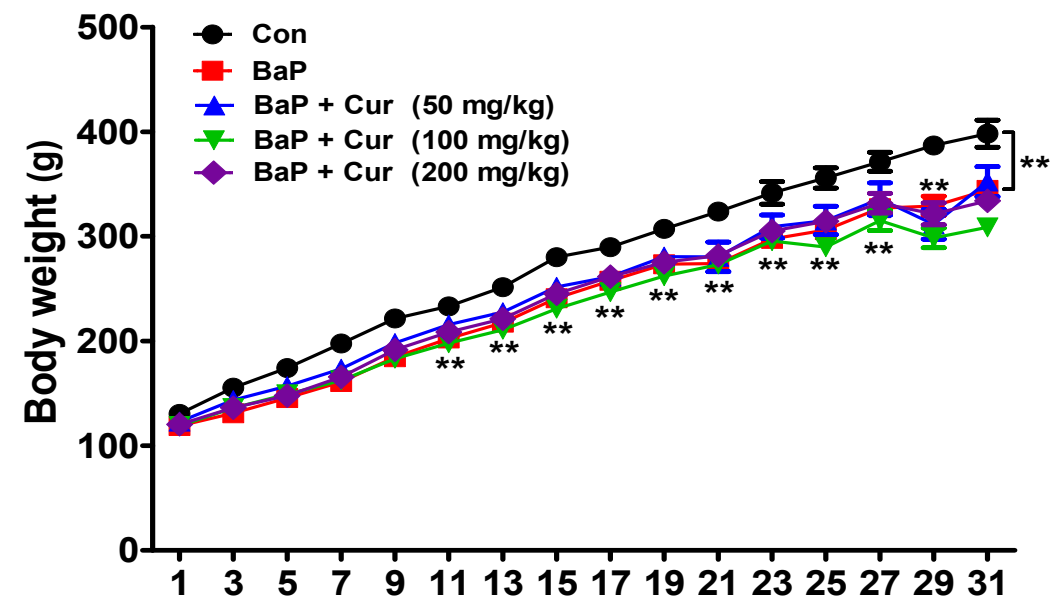

Figure 1. Effects of curcumin on body weight changes in rats treated with benzo(a)pyrene. Rats were orally administrated benzo[a]pyrene $(\mathrm{BaP})$ alone $(20 \mathrm{mg} / \mathrm{kg})$ or in combination with curcumin $(50,100$, or $200 \mathrm{mg} / \mathrm{kg}$ ) for 30 days. The control group was administered vehicle only. Values are indicated by mean \pm SEM of six animals. Significant difference from the control group at ${ }^{* *} p<0.01$. Cur: curcumin.

Table 1. Effects of Curcumin on Organ Weight Changes in Sprague-Dawley Rats.

\begin{tabular}{cccccc}
\hline \multirow{2}{*}{ Groups } & \multicolumn{5}{c}{ Organ Weights (g) } \\
\cline { 2 - 6 } & Liver & Kidney & Stomach & Spleen & Testis \\
\hline Control & $3.6 \pm 0.11$ & $0.35 \pm 0.01$ & $0.52 \pm 0.02$ & $0.19 \pm 0.01$ & $0.39 \pm 0.01$ \\
$\mathrm{BaP}(20 \mathrm{mg} / \mathrm{kg})$ & $3.8 \pm 0.10$ & $0.35 \pm 0.01$ & $0.53 \pm 0.03$ & $0.23 \pm 0.01$ & $0.43 \pm 0.02$ \\
$\mathrm{BaP}+\mathrm{Cur}(50 \mathrm{mg} / \mathrm{kg})$ & $3.2 \pm 0.07 *$ & $0.34 \pm 0.01$ & $0.48 \pm 0.03$ & $0.20 \pm 0.01$ & $0.39 \pm 0.01$ \\
$\mathrm{BaP}+$ Cur. $(100 \mathrm{mg} / \mathrm{kg})$ & $3.1 \pm 0.09 *$ & $0.33 \pm 0.02$ & $0.54 \pm 0.04$ & $0.21 \pm 0.01$ & $0.42 \pm 0.01$ \\
$\mathrm{BaP}+$ Cur. $(200 \mathrm{mg} / \mathrm{kg})$ & $2.9 \pm 0.09 *$ & $0.36 \pm 0.01$ & $0.55 \pm 0.02$ & $0.21 \pm 0.02$ & $0.42 \pm 0.02$ \\
\hline
\end{tabular}

Rats were orally administrated corn oil (control) or benzo[a]pyrene (BaP) alone (20 mg/kg) or in combination with curcumin $(50,100$, or $200 \mathrm{mg} / \mathrm{kg}$ ) for 30 days. The control group was administered the vehicle only. Values are indicated with mean \pm SD of six animals. Significant difference from the BaP alone group at ${ }^{*} p<0.05$.

Table 2. Effects of Curcumin on Serum Biochemical Parameters in Sprague-Dawley Rats.

\begin{tabular}{ccccc}
\hline Groups & \multicolumn{4}{c}{ Biochemical Parameters } \\
\hline & ALT (U/L) & AST (U/L) & BUN $(\mathrm{mg} / \mathrm{dL})$ & Glucose $(\mathrm{mg} / \mathrm{dL})$ \\
\hline Control & $53.0 \pm 3.3$ & $120.2 \pm 8.0$ & $11.9 \pm 0.3$ & $134.67 \pm 7.4$ \\
$\mathrm{BaP}(20 \mathrm{mg} / \mathrm{kg})$ & $61.4 \pm 2.1^{*}$ & $144.4 \pm 8.4^{*}$ & $20.7 \pm 1.8^{*}$ & $184.65 \pm 6.8^{*}$ \\
$\mathrm{BaP}+\mathrm{Cur}(50 \mathrm{mg} / \mathrm{kg})$ & $54.3 \pm 6.0$ & $127.6 \pm 8.5$ & $15.4 \pm 0.7$ & $144.1 \pm 10.1$ \\
$\mathrm{BaP}+$ Cur $(100 \mathrm{mg} / \mathrm{kg})$ & $45.9 \pm 5.8^{\#}$ & $121.2 \pm 5.9^{\#}$ & $12.9 \pm 1.1^{\# \#}$ & $115.0 \pm 14.9^{\# \#}$ \\
$\mathrm{BaP}+$ Cur $(200 \mathrm{mg} / \mathrm{kg})$ & $36.7 \pm 1.9^{\# \#}$ & $122.0 \pm 6.2^{\#}$ & $12.0 \pm 0.3^{\# \#}$ & $104.8 \pm 8.3^{\# \#}$ \\
\hline
\end{tabular}

Rats were orally administrated corn oil (control) or benzo[a]pyrene (BaP) alone (20 mg/kg) or in combination with curcumin $(50,100$, or $200 \mathrm{mg} / \mathrm{kg}$ ) for 30 days. The control group was administered the vehicle only. Values are indicated with mean \pm SD of six animals. ALT, alanine aminotransferase; AST, aspartate aminotransferase; BUN, blood urea nitrogen. Significant difference from the control group at $*<0.05$; Significant difference from the BaP alone group at ${ }^{\#} p<0.05$; Significant difference from the BaP alone group at ${ }^{\#} p<0.01$. 


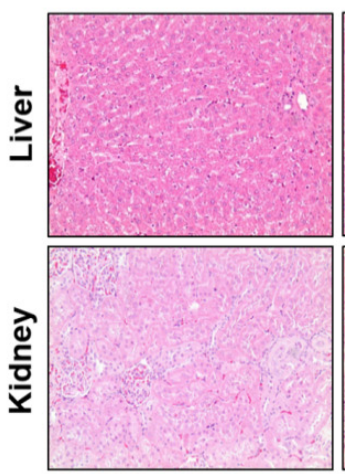

Con

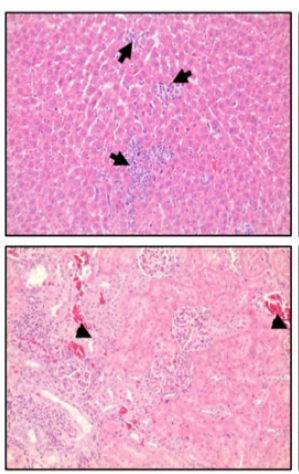

BaP

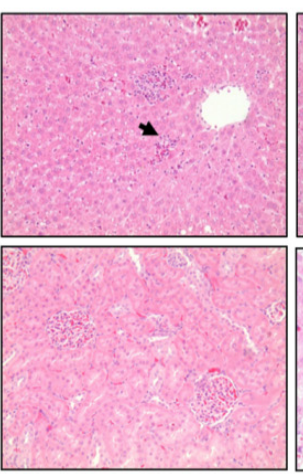

BaP+Cur

(50 $\mathrm{mg} / \mathrm{kg})$

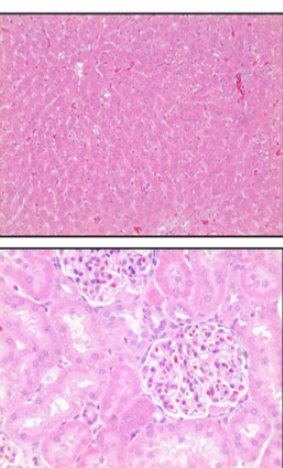

BaP+Cur

$(100 \mathrm{mg} / \mathrm{kg})$

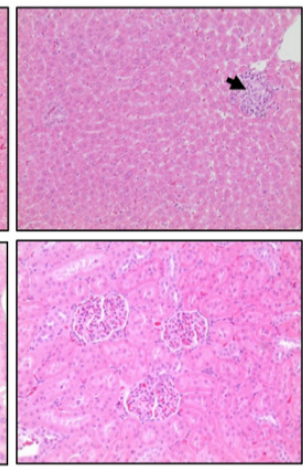

BaP+Cur (200 mg/kg)

Figure 2. Effects of curcumin on histopathological changes in liver and kidney of rats treated with benzo[a]pyrene $(\mathrm{BaP})$. Rats were orally administrated (BaP alone $(20 \mathrm{mg} / \mathrm{kg})$ or in combination with curcumin $(50,100$, or $200 \mathrm{mg} / \mathrm{kg}$ ) for 30 days. The control group was administered vehicle only. Representative histology of hematoxylin and eosin (H\&E)-stained liver and kidney sections from experimental groups. Arrows displayed cell infiltration, mononuclear cells, and multifocal cells. Arrowheads indicated focal nephropathy. Cur; curcumin. Original magnification: $\times 100$.

Table 3. Histopathological Changes in Liver and Kidney of Sprague-Dawley Rats.

\begin{tabular}{|c|c|c|c|c|c|}
\hline Groups & Control & $\mathrm{BaP}$ & $\begin{array}{l}\mathrm{BaP}+\mathrm{Cur} \\
(50 \mathrm{mg} / \mathrm{kg})\end{array}$ & $\begin{array}{c}\text { BaP + Cur } \\
(100 \mathrm{mg} / \mathrm{kg})\end{array}$ & $\begin{array}{c}\mathrm{BaP}+\mathrm{Cur} \\
(200 \mathrm{mg} / \mathrm{kg})\end{array}$ \\
\hline No. of animals examined & 6 & 6 & 6 & 6 & 6 \\
\hline \multicolumn{6}{|c|}{ Liver } \\
\hline No. of specific lesions & 5 & 0 & 2 & 2 & 2 \\
\hline $\begin{array}{l}\text { Cell infiltration, mononuclear cells, } \\
\text { multifocal cells }\end{array}$ & 1 & 6 & 4 & 4 & 4 \\
\hline Minimum & 1 & 6 & 4 & 3 & 4 \\
\hline Mild & 0 & 0 & 0 & 1 & 0 \\
\hline \multicolumn{6}{|c|}{ Kidney } \\
\hline No. of specific lesions & 4 & 1 & 4 & 4 & 6 \\
\hline Focal nephropathy & 2 & 5 & 2 & 1 & 0 \\
\hline Minimum & 0 & 5 & 2 & 1 & 0 \\
\hline Cell infiltration, lymphocytic & 0 & 0 & 0 & 0 & 0 \\
\hline Minimum & 0 & 0 & 0 & 0 & 0 \\
\hline
\end{tabular}

Rats were orally administrated corn oil (control) or benzo[a]pyrene $(\mathrm{BaP})$ alone $(20 \mathrm{mg} / \mathrm{kg})$ or in combination with curcumin $(50,100$, or $200 \mathrm{mg} / \mathrm{kg}$ ) for 30 days. The control group was administered the vehicle only. Values are indicated with mean \pm SD of six animals. Minimum: $<10$ foci; mild: 10-15 foci in a specimen. Cur; curcumin.

\subsection{Effect of Curcumin on Formation of BaP and its Metabolites in Serum of Rats}

To detect $\mathrm{BaP}$ and its metabolites, a spectrum of different wavelengths was tested to detect $\mathrm{BaP}$ or $\mathrm{BaP}$ metabolites. The eluted $\mathrm{BaP}$, as well as metabolite peak, was confirmed based on the internal standard (IS). For highest sensitivity of detection, $\mathrm{BaP}$ and its metabolites were separated by liquid chromatography tandem mass spectrometry (LC/MS/MS). Chromatographic profiles were almost baseline with the elution of $\mathrm{BaP}$ and metabolites, probably due to retaining the $\mathrm{BaP}$ and its metabolites on the resin under such conditions (Figure 3). We could detect the BaP metabolites in the serum including 3-hydroxy BaP (3-OH-BaP), 7-hydroxy BaP (7-OH-BaP), and BPDE. The co-administration of curcumin significantly reduced the concentration of 7-OH-BaP and BPDE when compared to the $\mathrm{BaP}$ alone group. In contrast, serum concentration of parent compound $\mathrm{BaP}$ was increased by co-administration of curcumin in a dose-dependent manner (Figure 4). 

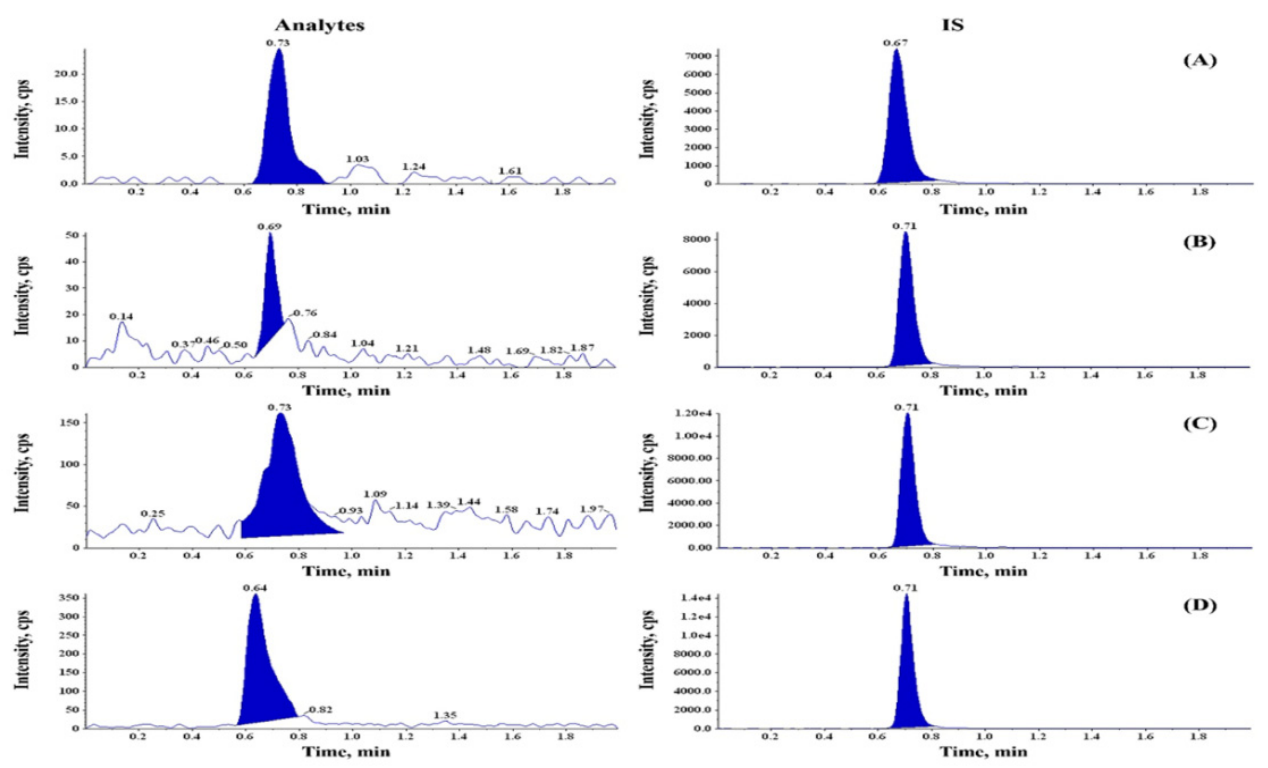

Figure 3. Separation of the benzo[a]pyrene and its metabolites in serum of rats. The analyses of the benzo[a]pyrene $(\mathrm{BaP})$ metabolites were detected using liquid chromatography tandem mass spectrometry (LC/MS/MS). Mobile phase; D.W (0.1\% formic acid): Acetonitrile $(0.1 \%$ formic acid) $=2: 98$, calibration curve: $\mathrm{R}=0.99$, with gradient program (2:98, D.W, containing $0.1 \%$ formic acid: Acetonitrile containing $1 \%$ formic acid) as a mobile phase. Chromatographic profiles as almost baseline without the elution of $\mathrm{BaP}$ and metabolites, probably due to retaining the $\mathrm{BaP}$ and its metabolites on the resin under such conditions. Left panels indicated the typical LC/MS/MS chromatogram of (A) $\mathrm{BaP}$; (B) 3-OH BaP; (C) 7-OH BaP; (D) BaP-diolepoxide (BPDE). Right panels indicated the typical LC/MS/MS chromatograms of internal standard (cryptotanshinone).
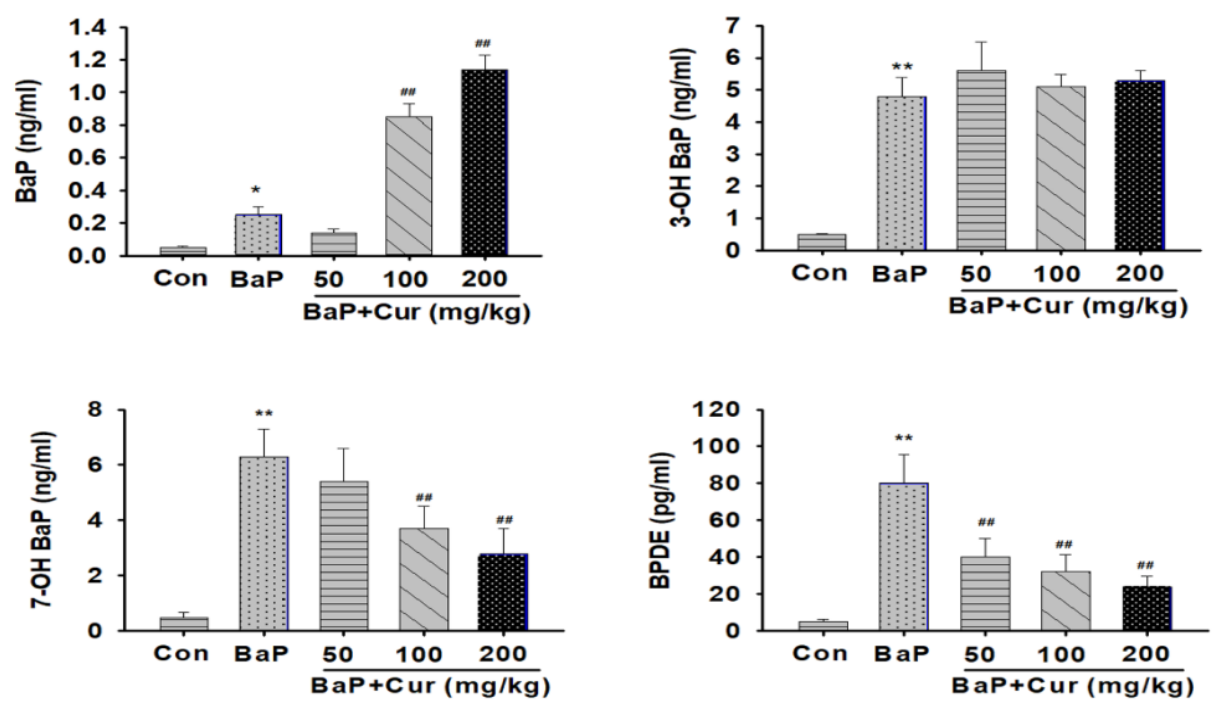

Figure 4. Effect of curcumin on the formation of major benzo[a]pyrene metabolites in serum of rats treated orally with benzo(a)pyrene. Rats were orally administrated benzo[a]pyrene (BaP) alone $(20 \mathrm{mg} / \mathrm{kg})$ or in combination with curcumin $(50,100$, or $200 \mathrm{mg} / \mathrm{kg})$ for 30 days. The analysis of BaP metabolite was detected using LC/MS/MS. The control group was administered vehicle only. Values are indicated by mean \pm SD of six animals. Significant difference from the control group at $p<0.05$; Significant difference from the control group at ${ }^{* *} p<0.01$; Significant difference from the BaP alone group at ${ }^{\# \#} p<0.01$. Cur: curcumin. 


\subsection{Effect of Curcumin on Expression of Hepatic CYPs in Rats}

The induction of cytochrome P450 (CYP)1A1 and CYP1B1 by environmental xenobiotic chemicals or endogenous ligands through the activation of the aryl hydrocarbon receptor (AhR) has been implicated in a variety of cellular processes related to cancer, such as transformation and tumorigenesis [31]. In our study, we measured the expression of CYP1A1 and CYP1B1 in the liver and stomach of experimental rats. In the BaP alone group, hepatic expression of CYP1A1 and CYP1B1 levels were highly increased, especially CYP1A1 levels (up to eight-fold compared with control). However, the co-administration of curcumin $(200 \mathrm{mg} / \mathrm{kg})$ with BaP markedly reduced the expression of CYP1A1 and CYP1B1 in the liver of rats (Figure 5). In the stomach tissues, CYP1A1 and CYP1B1 expression levels following the co-administration of curcumin were very similar to levels in the liver.
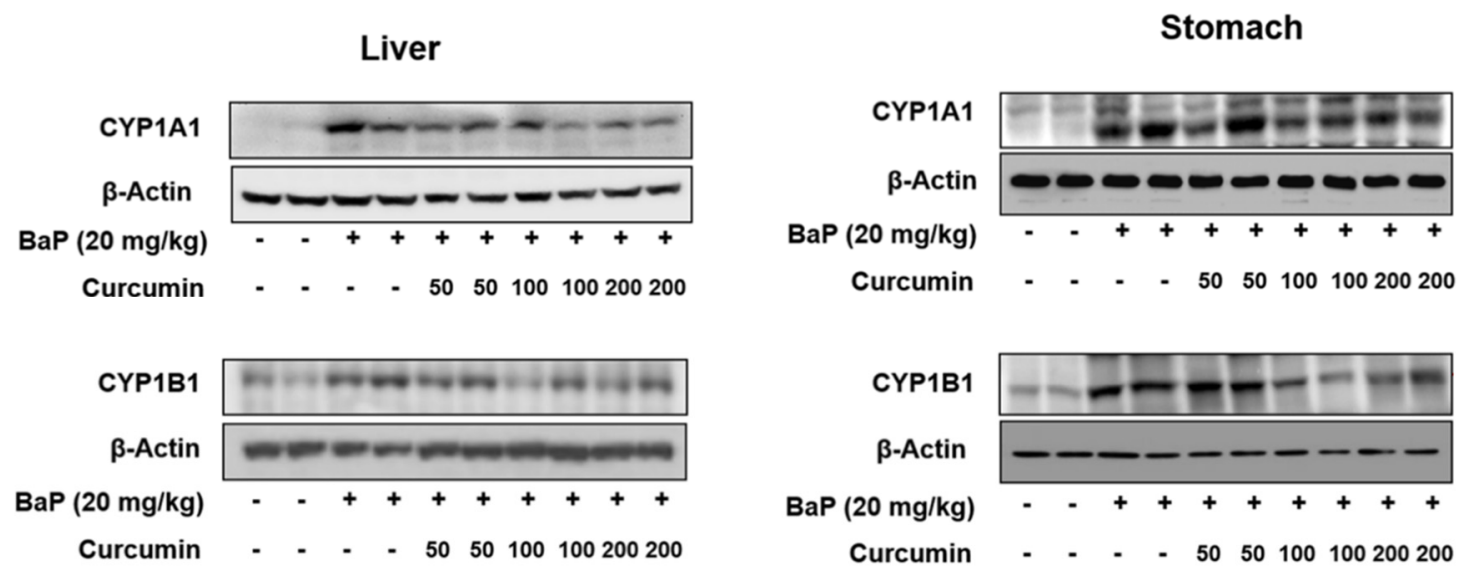

Figure 5. Effect of curcumin on the expression of cytochrome P450 (CYP)1A1 and CYP1B1 in liver and stomach of rats treated with benzo[a]pyrene $(\mathrm{BaP})$. Rats were orally administrated $\mathrm{BaP}$ alone $(20 \mathrm{mg} / \mathrm{kg})$ or in combination with curcumin $(50,100$, or $200 \mathrm{mg} / \mathrm{kg})$ for 30 days. The control group was administered vehicle only. Representative bands of western blot for CYP1A1 and CYP1B1 were shown. $\beta$-Actin was used as endogenous control to normalize the data.

\subsection{Effect of Curcumin on BaP-Induced DNA Damage in Rats}

To determine whether curcumin suppressed the BaP-induced DNA adduct formation, BPDE-I-DNA adduct levels were quantitated using ELISA. As shown in Figure 6, the BPDE-DNA adduct levels were significantly increased in the liver, kidney, and stomach of rats following BaP exposure, whereas the co-administration of curcumin significantly reduced BPDE-I-DNA adduct formation in a dose-dependent manner. Especially, BPDE-DNA adduct levels were inhibited in the stomach tissues following the co-administration of curcumin $(200 \mathrm{mg} / \mathrm{kg})$. These data are similar to the expression level of hepatic phase I enzyme levels because a significant inhibition of BaP-induced CYP1A1 and CYP1B1 was observed in the liver of curcumin-treated groups. Since curcumin markedly inhibited CYP1A1 and CYP1B1 from forming BPDE or other major BaP metabolites, it could also alter the DNA oxidative damage in the target organs. Therefore, levels of the oxidative DNA damage marker, 8-OHdG, were measured in response to reactive metabolites generated during BaP metabolism. The BaP-treated group showed a significant elevation of 8-OHdG levels in the liver and stomach tissues. However, significant inhibition of 8-OHdG levels was found in curcumin co-administered groups compared with BaP alone (Figure 7). Consequently, the sum total of the formation of DNA damage was reduced in a dose-dependent manner by the co-administration of curcumin when compared to BaP alone in rats. 

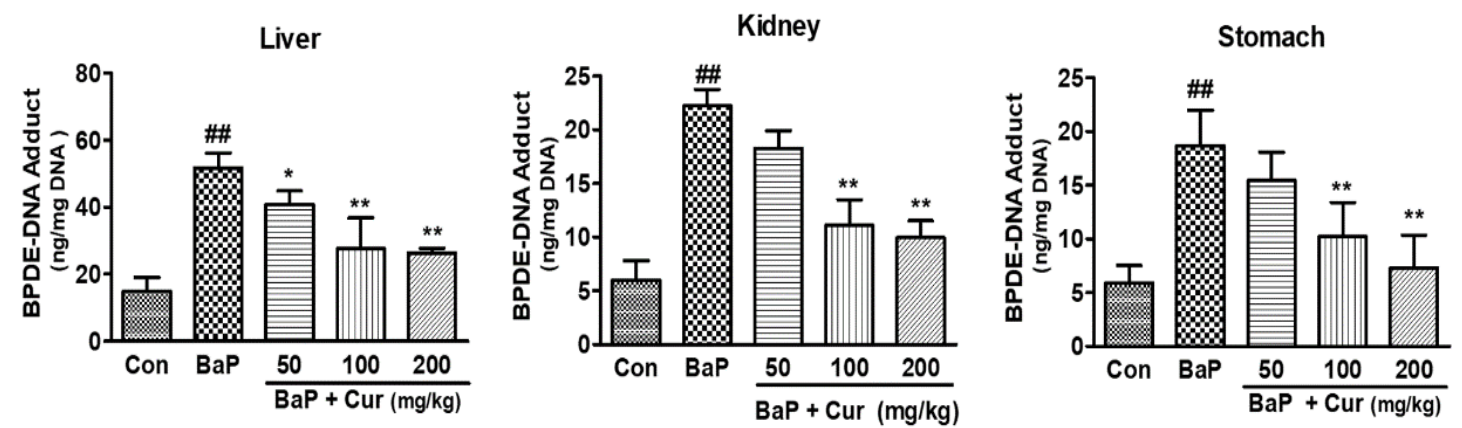

Figure 6. Effect of curcumin on the BPDE-DNA adducts formation in the target organs of Sprague-Dawley rats treated with benzo[a]pyrene $(\mathrm{BaP})$. Rats were orally administrated BaP alone $(20 \mathrm{mg} / \mathrm{kg})$ or in combination with curcumin $(50,100$, or $200 \mathrm{mg} / \mathrm{kg})$ for 30 days. The control group was administered vehicle only. Values are indicated by mean \pm SD of six animals. Significant difference from the control group at ${ }^{\# \#} p<0.01$; Significant difference from the $\mathrm{BaP}$ alone group at $p<0.05$; Significant difference from the BaP alone group at ${ }^{* *} p<0.01$. Cur: curcumin.
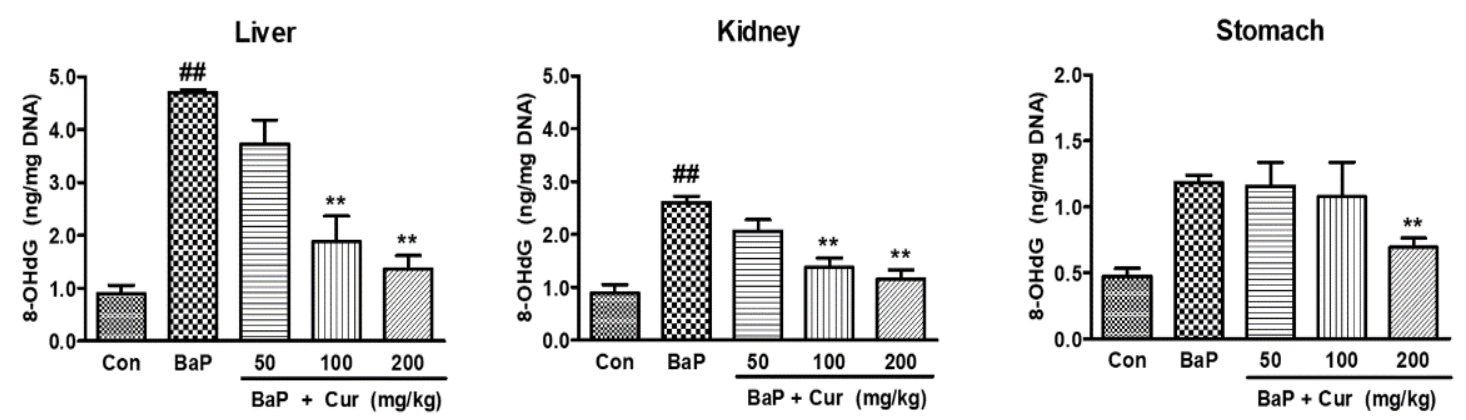

Figure 7. Effect of curcumin on the 8-hydroxydeoxyguanosine (8-OHdG) formation in the target organs of Sprague-Dawley rats treated with benzo[a]pyrene $(\mathrm{BaP})$. Rats were orally administrated BaP alone $(20 \mathrm{mg} / \mathrm{kg})$ or in combination with curcumin $(50,100$, or $200 \mathrm{mg} / \mathrm{kg}$ ) for 30 days. The control group was administered vehicle only. Values are indicated with mean \pm SD of six animals. Significant difference from the control group at ${ }^{\# \#} p<0.01$; Significant difference from the $\mathrm{BaP}$ alone group at ${ }^{* *} p<0.01$. Cur: curcumin.

\section{Discussion}

The present study investigated the protective role of curcumin against BaP-induced DNA damage in the target organs of rats. Although active metabolites BaP cause DNA damage in various tissues, little is known about the potential role of BaP-induced DNA damage in stomach carcinogenesis. Hence, we investigated whether curcumin suppressed $\mathrm{BaP}$-induced DNA adduct formation in the target organs. Taken together, this study provides new insights into the novel mechanisms of curcumin acting on the regulation of BaP metabolism, which may be important for understanding BaP-induced carcinogenesis. Our data indicated that curcumin administration significantly inhibited BaP-induced DNA damage in the stomach tissues compared with other organs by inhibiting BaP metabolism. Therefore, we suggest that dietary curcumin may inhibit $\mathrm{BaP}$-induced gastric tumorigenesis by reducing the formation of active $\mathrm{BaP}$ metabolites, as well as increasing the detoxification of $\mathrm{BaP}$ metabolites.

The molecular mechanism of BaP-induced carcinogenesis is closely related to DNA adduct formation and oxidative DNA damage through metabolic activation first oxidized by CYP1A1 and CYP1B1 to form intermediate metabolites, BaP-7,8-epoxide [32,33]. Through increased metabolic activation, BaP-7,8-epoxide changes to its ultimate carcinogen, anti-BPDE-I, which covalently binds to DNA to form BPDE-DNA adducts [34]. DNA adducts induced by BaP in various organs have been studied as biomarkers for PAH exposure or toxicity [35]. Although DNA adducts are used as biomarkers for chemical exposure to clarify genotoxic and nongenotoxic carcinogens, they may not accurately predict with certainty their carcinogenic potential in the target organs. A previous study 
showed that acute exposure to BaP by oral gavage leads to similar levels of DNA adduct formation in the lungs and livers, which are BaP-bioactivating organs [36]. The present study was undertaken to further explore the gastric carcinogenesis underlying such distinct tissue-specific responses using a subchronic BaP exposure model.

$\mathrm{BaP}$ also produces a few quinone derivatives and reactive oxygen species (ROS), which are mutagens and carcinogens, during BaP metabolic activation [37]. ROS was generated as intermediate metabolites and damages proteins, lipids, and DNA [32,38,39]. In particular, the formation of 8-OHdG has been widely used as a biomarker of oxidative DNA damage [40]. We found that the co-administration of curcumin resulted in increased plasma concentration of unmetabolized BaP and decreased concentration of intermediate metabolites including 7-OH-BaP and BPDE, indicating that curcumin inhibited the active metabolites formation from BaP. Therefore, our data support that the formation of DNA-adduct concentration may have been reduced in the blood. As expected, BaP-induced DNA adducts patterns were concurrent with protein expression levels of CYP1A1 and CYP1B1 and its active metabolites formation. Although there is a linear correlation between mutation frequency and tumor incidence in target organs after exposure of animals to $\mathrm{BaP}$, the levels of BaP-DNA adduct formation did not distinguish target (lung, spleen, and forestomach) from non-target organs (liver, colon and glandular stomach) in mice following oral administration of BaP [41]. This study was very similar to our present data that oral exposure to BaP significantly increased BPDE-I-DNA adduct formation in the stomach and liver tissues. Induction of CYP1A1 and CYP1B1 by environmental xenobiotic chemicals or endogenous ligands through the activation of the aryl hydrocarbon receptor (AhR) has been implicated in a variety of cellular processes related to cancer, such as transformation and tumorigenesis [31,41]. Here, we investigated the effects of curcumin on expression of CYP1A1 and CYP1B1 in the liver and stomach of rats treated with BaP for 30 days. We found that curcumin significantly inhibited CYP1A1 expression in the liver and stomach to protect the formation of BaP active metabolites.

The underlying mechanisms of chemoprevention may be induced not only because curcumin possesses good ROS scavenging abilities, but curcumin may also be capable of inhibiting BaP metabolism enzymes. Sehgal et al. (2013) demonstrated that curcumin suppresses BaP-induced DNA damage in liver and lung of mice by increasing the activity of ethoxyresorufin-O-deethylase (EROD) [42]. Zhu et al. (2014) found that curcumin inhibited CYP1A1 and CYP1A1-catalyzed 7,8-diol-BaP-epoxidation, which is the terminal reaction leading to the ultimate carcinogenic product, diolepoxide, in lung epithelial cells [43]. The data from the above studies suggest that the protective effects of curcumin against BaP-induced DNA damage and precancerous changes in cells are initiated upstream from CYP1A1. Therefore, the protective effects of curcumin against BPDE-DNA adduct formation in the stomach is related to inhibition of CYP1A1 and CYP1A2 expression, rather than inhibition of the enzyme activity itself. These results suggest that while unrepaired DNA adducts were formed in the stomach, other factors, such as alterations in critical molecular processes implicated in cancer formation, may play a role in the selective targeting of the stomach tissue following BaP exposure.

Another mechanism of inhibition of DNA adduct formation by curcumin is the inactivation of BaP-derived reactive metabolites such as ROS and BaP-quinone derivatives. In the present study, we showed a clear inverse relationship between curcumin dose and the level of BPDE-DNA adducts. However, curcumin is indeed capable of protecting against ROS formation. For the DNA damages and the precancerous pathologic changes in cells that can lead to carcinogenesis, this is also the potential mechanism for the chemopreventive effects of curcumin during carcinogenesis induced by BaP and other procarcinogens. Therefore, curcumin protects the BaP-induced 8-OHdG formation in target tissues including the liver, kidney, and stomach. 


\section{Materials and Methods}

\subsection{Chemicals and Reagents}

$\mathrm{BaP}$, nuclease P1, and curcumin were purchased from Sigma-Aldrich (St. Louis, MO, USA). Alkaline phosphatase was purchased from Takara Bio Inc. (Shiga, Japan). All other western blot reagents were from Merck Millipore (Burlington, MA, USA). Primary antibodies (CYP 1A1, CYP 1B1, and $\beta$-actin) and a horseradish peroxidase (HRP)-conjugated secondary antibody were purchased from Santa Cruz Biotechnology (Santa Cruz, CA, USA). The Genomic DNA isolation kit was purchased from Qiagen (Venlo, Netherlands). All enzyme-linked immunosorbent assay (ELISA) kits were purchased from Cell Biolabs Inc. (BPDE-DNA adduct kit no. STA-357, 8-OHdG kit no. STA-320; San Diego, CA, USA). Hematoxylin and eosin were purchased from Dako (Glostrup, Denmark).

\subsection{Animal Experiments}

Sprague-Dawley rats (five-week-old males, weighing 140-150 g) were obtained from Orient-Bio (Seongnam-si, Korea). All animals were maintained in a specific pathogen free (SPF)-conditioned room with a 12-h light/dark cycle. The ambient air temperature and relative humidity was set to $23 \pm 2{ }^{\circ} \mathrm{C}$ and 55\%, respectively. Before the experiments, all animals were checked for any overt signs of illness and only healthy animals were selected. Rodent chow and water were supplied ad libitum. The experimental protocol was approved by Sungkyunkwan University Laboratory Animal Care Service (SKKU-2013-000105, March 23, 2013) in accordance with the Ministry of Food and Drug Safety (MFDS) Animal Protection of Korea (Oh-Song, Korea). Animals in each group $(n=6)$ were randomly divided into five groups: (1) Control group, where rats were treated with corn oil for 30 days; (2) BaP-treated group, where rats were administered orally BaP (20 mg/kg) dissolved in corn oil for 30 days; and (3) co-treatment of BaP and curcumin groups, where curcumin (50, 100, or $200 \mathrm{mg} / \mathrm{kg}$ ) was administered orally before $\mathrm{BaP}(20 \mathrm{mg} / \mathrm{kg})$ exposure for 30 days. The inclusion of BaP concentrations was chosen based on other studies $[44,45]$. The BaP doses employed in our study are relevant to human exposure scenarios, as the levels of pulmonary arterial hypertension (PAH) are similar to levels that would be acquired in the diet [34]. If a young adult weighing $50 \mathrm{~kg}$ were to eat a half-pound $(0.23 \mathrm{~kg}$ ) of fried chicken (containing $5 \mu \mathrm{g} / \mathrm{kg}$ ) or charcoal-broiled steak (containing $9 \mu \mathrm{g} / \mathrm{kg}$ ) every day, it translates to a PAH dose of 30-50 ng/kg/day [46]. Some studies have reported a total PAH intake of $14 \mu \mathrm{g} / \mathrm{kg} / \mathrm{day}$ [47] and $59.2 \mu \mathrm{g} / \mathrm{kg} / \mathrm{day}$ [48], and a more recent report listed an intake of $371 \mu \mathrm{g} /$ person/day [1] The treatments were administered daily at the same time, and animals were acclimated for $1 \mathrm{~h}$ before treatment.

\subsection{Biochemical Parameters in Serum}

Blood was collected from the abdominal aorta and collected in 15-mL plain tubes. Within $1 \mathrm{~h}$ of collection, blood samples were then centrifuged at $3000 \times g$ for $10 \mathrm{~min}$ to collect serum. The sera were immediately stored at $-80^{\circ} \mathrm{C}$ to analyze blood urea nitrogen (BUN) and glucose levels, as well as ALT and AST activities, using an Olympus AU400 chemistry analyzer (Tokyo, Japan).

\subsection{Determination of the BaP and BaP Metabolites in Plasma}

\subsubsection{LC/MS/MS Analysis}

For the analysis of $\mathrm{BaP}$, 3-hydroxy $\mathrm{BaP}$ (3-OH BaP), 7-hydroxy BaP (7-OH BaP), and BaP-7,8-dihydrodiol-9,10-epoxide (BPDE) concentration in plasma, a LC/MS/MS method was developed. A liquid chromatographic system (Dionex Ultimate ${ }^{\circledR}$ 3000, Thermo Fisher Scientific Inc., Boston, MA, USA) equipped with a pump, autosampler, and column compartment was used and connected to a quadrupole tandem mass spectrometer (AB SCIEX API 3200, Applied Biosystems Sciex, Toronto, Ontario, Canada) equipped with an atmospheric pressure chemical ionization (APCI) source. System control and data analyses were carried out with Analyst 1.5.2. Chromatographic separation 
was performed using a Unison UK C8 $(75 \times 2.0 \mathrm{~mm}, 3 \mu \mathrm{m}$, Imtakt, Kyoto, Japan) protected by a guard column $\left(4.0 \times 2.0 \mathrm{~mm}\right.$, Phenomenex, Torrance, CA, USA). The column oven temperature was $40{ }^{\circ} \mathrm{C}$. The mobile phase of $0.1 \%$ formic acid in water for the A pump and $0.1 \%$ formic acid in acetonitrile for the B pump $(2: 98, v / v)$ was run at a flow rate of $400 \mathrm{~mL} / \mathrm{min}$. The injection volume was $10 \mu \mathrm{L}$ and the total analysis run time was $2 \mathrm{~min}$. The atmospheric pressure chemical ionization (APCI) mass spectrometer was operated in the positive ion mode. Multiple reaction monitoring (MRM) of the precursor-product ion transitions from m/z 253.0 to m/z 250.0 for BaP, from m/z 269.0 to m/z 252.0 for 3-OH BaP, from m/z 269.0 to m/z 241.0 for 7-OH BaP, and from m/z 304.1 to m/z 258.2 for BPDE were used for quantitation. Collision energy of BaP, 3-OH BaP, 7-OH BaP, and BPDE was 77, 40, 30, and $17 \mathrm{~V}$, respectively. The optimized conditions were as follows: Nebulizer current $(5 \mu \mathrm{A})$, curtain gas (30 psi), collision gas $(5 \mathrm{psi})$, ion spray voltage $(5500 \mathrm{~V})$, source temperature $\left(300^{\circ} \mathrm{C}\right)$, and ion source gas 1 (30 psi).

\subsubsection{Preparation of Stock Solution and Standard Solution}

A stock solution of $\mathrm{BaP}, 3-\mathrm{OH} \mathrm{BaP}, 7-\mathrm{OH} \mathrm{BaP}$, and BPDE was prepared in acetonitrile at $1.0 \mathrm{mg} / \mathrm{mL}$ and dilution solutions of stock solution were used with $0.1 \%$ formic acid in $50 \%$ acetonitrile. Standard solutions of $\mathrm{BaP}, 3-\mathrm{OH} \mathrm{BaP}, 7-\mathrm{OH} \mathrm{BaP}$, and $\mathrm{BPDE}$ were prepared by spiking with an appropriate volume of the diluted stock solution, giving final concentrations of 10, 50, 100, 500, and $1000 \mathrm{ng} / \mathrm{mL}$. The internal standard (IS, cryptotanshinone) solution was prepared in acetonitrile and diluted with $0.1 \%$ formic acid in $50 \%$ acetonitrile to give a final concentration of $1 \mu \mathrm{g} / \mathrm{mL}$.

\subsubsection{Sample Preparation}

Plasma was prepared through a liquid-liquid extraction method. A 50- $\mu \mathrm{L}$ aliquot of plasma was spiked with $5 \mu \mathrm{L}$ of IS $(1 \mu \mathrm{g} / \mathrm{mL})$ in a 1.5-mL polyethylene micro tube. Next, $500 \mu \mathrm{L}$ of ethyl acetate was added as an extraction solvent to the tubes. The tubes were vortex-mixed for $1 \mathrm{~min}$ and centrifuged (Hanil Science Industrial Co. Ltd., Incheon, South Korea) for $5 \mathrm{~min}$ at 12,000 $\times g$. The organic layer was transferred to another microtube and evaporated under nitrogen gas at $40^{\circ} \mathrm{C}$ in a MG 2100 Eyela dry thermo bath (Rikakikai Company, Tokyo, Japan). Then, $100 \mu \mathrm{L}$ of the $0.1 \%$ formic acid in $98 \%$ acetonitrile was added as mobile phase to reconstitute the residue and $100 \mu \mathrm{L}$ of the supernatant was directly injected to the HPLC system. The injection volume was kept at $10 \mu \mathrm{L}$.

\subsubsection{Calibration Curve}

The calibration standards used were 10, 50, 100, 500, 1000, and $2000 \mathrm{ng} / \mathrm{mL}$ of BaP, 3-OH BaP, 7-OH $\mathrm{BaP}$, and BPDE in plasma. These plasma samples were extracted as described above in the sample preparation section. Calibration curves of $\mathrm{BaP}, 3-\mathrm{OH} \mathrm{BaP}, 7-\mathrm{OH} \mathrm{BaP}$, and BPDE were constructed using the weighted regression method $\left(\mathrm{R}=0.999,1 / \mathrm{x}^{2}\right.$, weighting) by plotting the peak area ratio of analytes and IS versus the concentrations. The lower limit of quantitation (LLOQ) was $10 \mathrm{ng} / \mathrm{mL}$ for all four compounds.

\subsection{Protein Preparation and Western Blot Analysis}

The liver and stomach were detached immediately, rinsed with cold phosphate-buffered saline (PBS), and stored at $-80{ }^{\circ} \mathrm{C}$. Tissues were thawed and homogenized using PRO-PREP ${ }^{\mathrm{TM}}$ protein extract solution (iNtRON, Seongnam, Korea). Protein was quantitated using the protein assay reagent (Pierce, Rockford, IL, USA) according to the manufacturer's instructions. Extracted proteins were denatured by boiling at $95{ }^{\circ} \mathrm{C}$ for $5 \mathrm{~min}$ in sample buffer (0.5 M Tris-HCL, pH 6.8, 4\% SDS, 20\% glycerol, $0.1 \%$ bromophenol blue, $10 \% \beta$-mercaptoethanol). Protein samples (30 $\mu \mathrm{g}$ ) were run on $8 \sim 12 \%$ SDS-polyacrylamide gel electrophoresis (SDS-PAGE) at $100 \mathrm{~V}$ for $90 \mathrm{~min}$ using running buffer $(25 \mathrm{mM}$ Tris, $192 \mathrm{mM}$ glycine, $0.1 \%$ SDS). The proteins were electrophoretically transferred to polyvinylidene difluoride (PVDF) membranes (Millipore, Burlington, MA, USA) at $100 \mathrm{~V}$ for $90 \mathrm{~min}$ in transfer buffer (25 mM Tris- $\mathrm{HCl}$ pH 9.5, $192 \mathrm{nM}$ glycine, 20\% Methanol). The membranes were then blocked using 
blocking buffer (TNT buffer containing $5 \%$ skim milk) for $1 \mathrm{~h}$. Next, membranes were incubated overnight at $4{ }^{\circ} \mathrm{C}$ with primary antibodies (CYP1A1, CYP1B1, and $\beta$-actin). After washing for $60 \mathrm{~min}$ with TNT buffer (10 mM Tris- $\mathrm{HCl}, \mathrm{pH} 7.6,100 \mathrm{mM} \mathrm{NaCl}$, and $0.5 \%$ Tween 20), the membranes were incubated for $60 \mathrm{~min}$ with HRP-conjugated goat anti-rabbit IgG $(1: 10,000)$ or anti-mouse IgG (1:8000), and then washed for 90 min with TNT buffer. The blots were developed using an Enhanced chemiluminescence (ECL)-plus kit (Amersham Biosciences, Amersham, Buckinghamshire, UK).

\subsection{Quantitation of BPDE-DNA Adducts}

The ELISA kit was purchased from Cell Biolabs Inc. (San Diego, CA, USA). The formation of BPDE-DNA adducts was determined using enzyme-linked immunoassay following the manufacturer's protocol. DNA was extracted from the stomach and liver using QIAamp DNA Mini Kit. Briefly, $100 \mu \mathrm{L}$ of unknown DNA sample and standards were incubated for $2 \mathrm{~h}$ at $37^{\circ} \mathrm{C}$. The solutions were removed and washed two times using PBS, and $100 \mu \mathrm{L}$ of anti-BPDE-I antibody was added and incubated for $1 \mathrm{~h}$ at room temperature. Then, wells were washed five times with washing buffer and each well was blocked using blocking solution. After removal of solutions and washing with washing buffer three times, wells were incubated with secondary antibody at room temperature for $1 \mathrm{~h}$ and then washed three times. Next, $100 \mu \mathrm{L}$ of 3,3',5,5'-tetramethylbenzidine (TMB) solution was added to each well and incubated for $20 \mathrm{~min}$ at room temperature. The reactions were stopped using stop solution, and absorbance was measured using a microplate reader (Molecular Devices, model VERSA max ${ }^{\mathrm{TM}}$, San Jose, CA, USA) at $450 \mathrm{~nm}$.

\subsection{Determination of 8-hydroxydeoxyguanosine}

The ELISA kits for quantitating 8-hydroxydeoxyguanosine (8-OHdG) were purchased from Cell Biolabs Inc. The assay was performed following instructions of the manual. Briefly, DNA was isolated from tissues and then incubated at $95^{\circ} \mathrm{C}$ for $5 \mathrm{~min}$ and rapidly chilled on ice. DNA samples were digested to nucleosides by incubating the denatured DNA with 10 units of nuclease $\mathrm{P} 1$ for $2 \mathrm{~h}$ at $37^{\circ} \mathrm{C}$ in $20 \mathrm{mM}$ sodium acetate ( $\mathrm{pH}$ 5.2), treated with 10 units of alkaline phosphatase (Takara Bio Inc.) for $15 \mathrm{~min}$ at $37^{\circ} \mathrm{C}$, and then incubated at $50^{\circ} \mathrm{C}$ for $15 \mathrm{~min}$ in $100 \mathrm{mM}$ Tris buffer (pH 7.5). The reaction mixture was centrifuged for $5 \mathrm{~min}$ at $6000 \times g$ and the supernatant were used for the assay. Simply, $50 \mu \mathrm{L}$ of unknown samples or standards were incubated at room temperature for $10 \mathrm{~min}$, then $50 \mu \mathrm{L}$ of the diluted anti-8-OHdG antibody was added and incubated at room temperature for $1 \mathrm{~h}$ on an orbital shaker. After washing three times, $100 \mu \mathrm{L}$ of diluted secondary antibody-enzyme conjugate was added and incubated at room temperature for $1 \mathrm{~h}$ before washing three times. Substrate solution $(100 \mu \mathrm{L})$ was added to each well and incubated at room temperature for $20 \mathrm{~min}$. The enzyme reaction was stopped by adding $100 \mu \mathrm{L}$ of stop solution, and absorbance was measured using the microplate reader at $450 \mathrm{~nm}$.

\subsection{Statistical Analysis}

All values are expressed as the mean \pm standard error of the mean (SEM). Statistical analysis was performed using SigmaStat (SPSS Inc., Chicago, IL, USA). Statistically significant differences were determined using one-way analysis of variance (ANOVA) followed by Dunn's test. A $p$-value $<0.05$ was considered statistically significant.

\section{Conclusions}

In summary, our results showed that curcumin has a protective effect against BaP-induced DNA damages by the inhibiting expression of phase I enzymes in the liver and stomach, ultimately inhibiting DNA adducts formation in the target organs. Especially, stomach tissue was perfectly protected DNA damages by curcumin during BaP-induced carcinogenesis. Our results suggest that curcumin significantly protected against gastric carcinogenesis through dietary exposure of $\mathrm{BaP}$, which is related to the inhibition of $\mathrm{BaP}$ metabolic activation and ROS generation. 
Author Contributions: H.S.K., H.G.J., and Y.G.K.; designed the experiments and drafted the manuscript, N.Y.K. and Y.G.K.; BaP or BaP metabolites analysis, K.S.K., J.Y.S., J.H.P., and S.H.L.; carried out sample isolation, western blotting, and statistical analyses, K.S.K., J.Y.S., H.R.K., and B.K.; performed the animal experiments, K.S.K. and J.Y.S.; data curation, K.S.K. and H.S.K.; writing-original draft preparation, H.S.K., H.G.J. and B.M.L. writing-review and editing.

Funding: This research was supported by a grant (13182MFDS767) from the Ministry of Food and Drug Safety, Korea in 2013.

Conflicts of Interest: The authors declare that they have no conflict of interest.

\section{References}

1. Li, J.; Fan, R.; Lu, S.; Zhang, D.; Zhou, Y.; Lv, Y. Exposure to polycyclic aromatic hydrocarbons could cause their oxidative DNA damage: A case study for college students in Guangzhou, China. Environ. Sci. Pollut. Res. Int. 2015, 22, 1770-1777. [CrossRef] [PubMed]

2. Boström, C.E.; Gerde, P.; Hanberg, A.; Jernström, B.; Johansson, C.; Kyrklund, T.; Rannug, A.; Törnqvist, M.; Victorin, K.; Westerholm, R. Cancer risk assessment, indicators, and guidelines for polycyclic aromatic hydrocarbons in the ambient air. Environ. Health Perspect. 2002, 110, 451-488.

3. Juhasz, A.L.; Naidu, R. Biodegradation, Bioremediation of high molecular weight polycyclic aromatic hydrocarbons: A review of the microbial degradation of benzo[a]pyrene. Int. Biodeter. Bioderg. 2000, 45, 57-88. [CrossRef]

4. Knuckles, M.E.; Inyang, F.; Ramesh, A. Acute and subchronic oral toxicities of benzo[a]pyrene in F-344 rats. Toxicol. Sci. 2001, 61, 382-388. [CrossRef] [PubMed]

5. Collins, J.F.; Brown, J.P.; Alexeeff, G.V.; Salmon, A.G. Pharmacology, potency equivalency factors for some polycyclic aromatic hydrocarbons and polycyclic aromatic hydrocarbon derivatives. Regul. Toxicol. Pharmacol. 1998, 28, 45-54. [CrossRef]

6. Alomirah, H.; Al-Zenki, S.; Al-Hooti, S.; Zaghloul, S.; Sawaya, W.; Ahmed, N.; Kannan, K. Concentrations and dietary exposure to polycyclic aromatic hydrocarbons (PAHs) from grilled and smoked foods. Food Control. 2011, 22, 2028-2035. [CrossRef]

7. Waldman, J.M.; Lioy, P.J.; Greenberg, A.; Butler, J.P. Analysis of human exposure to benzo (a) pyrene via inhalation and food ingestion in the Total Human Environmental Exposure Study (THEES). J. Expo. Anal. Environ. Epideminol. 1991, 1, 193-225.

8. Chien, Y.C.; Yeh, C.T. Excretion kinetics of urinary 3-hydroxybenzo[a]pyrene following dietary exposure to benzo a pyrene in humans. Arch. Toxicol. 2012, 86, 45-53. [CrossRef]

9. Culp, S.J.; Gaylor, D.W.; Sheldon, W.G.; Goldstein, L.S.; Beland, F.A. A comparison of the tumors induced by coal tar and benzo [a] pyrene in a 2-year bioassay. Carcinogenesis 1998, 19, 117-124. [CrossRef]

10. Trédaniel, J.; Boffetta, P.; Buiatti, E.; Saracci, R.; Hirsch, A. Tobacco smoking and gastric cancer: Review and meta-analysis. Int. J. Cancer 1997, 72, 565-573. [CrossRef]

11. Sjödahl, K.; Jansson, C.; Bergdahl, I.A.; Adami, J.; Boffetta, P.; Lagergren, J. Airborne exposures and risk of gastric cancer: A prospective cohort study. Int. J. Cancer 2007, 120, 2013-2018. [CrossRef] [PubMed]

12. Dungal, N.; Sigurjónsson, J. Gastric cancer and diet. A pilot study on dietary habits in two districts differing markedly in respect of mortality from gastric cancer. Br. J. Cancer 1967, 21, 270-276. [CrossRef] [PubMed]

13. Wogan, G.N.; Hecht, S.S.; Felton, J.S.; Conney, A.H.; Loeb, L.A. Environmental and chemical carcinogenesis, Semin. Cancer Biol. 2004, 14, 473-486. [CrossRef] [PubMed]

14. Athar, M.; Khan, W.A.; Mukhtar, H. Effect of dietary tannic acid on epidermal, lung, and forestomach polycyclic aromatic hydrocarbon metabolism and tumorigenicity in Sencar mice. Cancer Res. 1989, 49, 5784-5788.

15. Vauhkonen, M.; Kuusi, T.; Kinnunen, P.K. Serum and tissue distribution of benzo[a]pyrene from intravenously injected chylomicrons in rat in vivo. Cancer Lett. 1980, 11, 113-119. [CrossRef]

16. Withey, J.R.; Shedden, J.; Law, F.C.; Abedini, S. Distribution of benzo a pyrene in pregnant rats following inhalation exposure and a comparison with similar data obtained with pyrene. J. Appl. Toxicol. 1993, 13, 193-202. [CrossRef]

17. Kamangar, F.; Dores, G.M.; Anderson, W.F. Patterns of cancer incidence, mortality, and prevalence across five continents: Defining priorities to reduce cancer disparities in different geographic regions of the world. J. Clin. Oncol. 2006, 24, 2137-2150. [CrossRef] 
18. Nagini, S. Carcinoma of the stomach: A review of epidemiology, pathogenesis, molecular genetics and chemoprevention. World J. Gastroint. Oncol. 2012, 4, 156-169. [CrossRef]

19. Resende, C.; Ristimäki, A.; Machado, J.C. Genetic and epigenetic alteration in gastric carcinogenesis. Helicobacter 2010, 15, 34-39. [CrossRef]

20. Shi, J.; Qu, Y.P.; Hou, P. Pathogenetic mechanisms in gastric cancer. World J. Gastroenterol. 2014, 20, 13804-13819. [CrossRef]

21. Wattenberg, L.W. Inhibitory effects of benzyl isothiocyanate administered shortly before diethyl- nitrosamine or benzo[a]pyrene on pulmonary and forestomach neoplasia in A/J mice. Carcinogenesis 1987, 8, 1971-1973. [CrossRef] [PubMed]

22. Mehta, K.; Pantazis, P.; McQueen, T.; Aggarwal, B.B. Antiproliferative effect of curcumin (diferuloyl- methane) against human breast tumor cell lines. Anticancer Drugs 1997, 8, 470-481. [CrossRef] [PubMed]

23. Hidaka, H.; Ishiko, T.; Furuhashi, T.; Kamohara, H.; Suzuki, S.; Miyazaki, M.; Ikeda, O.; Mita, S.; Setoguchi, T.; Ogawa, M. Curcumin inhibits interleukin 8 production and enhances interleukin 8 receptor expression on the cell surface: Impact on human pancreatic carcinoma cell growth by autocrine regulation. Cancer 2002, 95, 1206-1214. [CrossRef] [PubMed]

24. Chen, A.; Xu, J.; Johnson, C. Curcumin inhibits human colon cancer cell growth by suppressing gene expression of epidermal growth factor receptor through reducing the activity of the transcription factor Egr-1. Oncogene 2006, 25, 278-288. [CrossRef]

25. Park, W.; Amin, A.R.; Chen, Z.G.; Shin, D.M. New perspectives of curcumin in cancer prevention. Cancer Prev. Res. 2013, 6, 387-400. [CrossRef]

26. Sarkar, A.; De, R.; Mukhopadhyay, A.K. Curcumin as a potential therapeutic candidate for Helicobacter pylori associated diseases. World J. Gastroenterol. 2016, 22, 2736-2748. [CrossRef]

27. Singh, S.V.; Hu, X.; Srivastava, S.K.; Singh, M.; Xia, H.; Orchard, J.L.; Zaren, H.A. Mechanism of inhibition of benzo[a]pyrene-induced forestomach cancer in mice by dietary curcumin. Carcinogenesis 1998, 19, 1357-1360. [CrossRef]

28. Azuine, M.A.; Kayal, J.J.; Bhide, S.V. Protective role of aqueous turmeric extract against mutagenicity of direct-acting carcinogens as well as benzo [alpha] pyrene-induced genotoxicity and carcinogenicity. J. Cancer Res. Clin. Oncol. 1992, 118, 447-452. [CrossRef]

29. Huang, M.T.; Ma, W.; Lu, Y.P.; Chang, R.L.; Fisher, C.; Manchand, P.S.; Newmark, H.L.; Conney, A.H. Effects of curcumin, demethoxycurcumin, bisdemethoxycurcumin and tetrahydrocurcumin on 12-O-tetradecanoylphorbol-13-acetate induced tumor promotion. Carcinogenesis 1995, 16, 2493-2497. [CrossRef]

30. Strimpakos, A.S.; Sharma, R.A. Curcumin: Preventive and therapeutic properties in laboratory studies and clinical trials. Antioxid. Redox Signal. 2008, 10, 511-546. [CrossRef]

31. Do, M.T.; Kim, H.G.; Tran, T.T.P.; Khanal, T.; Choi, J.H.; Chung, Y.C.; Jeong, T.C.; Jeong, H.G. Metformin suppresses CYP1A1 and CYP1B1 expression in breast cancer cells by down-regulating aryl hydrocarbon receptor expression. Toxicol. Appl. Pharmacol. 2014, 280, 138-148. [CrossRef] [PubMed]

32. Gelboin, H.V. Benzo[ $\alpha]$ pyrene metabolism, activation and carcinogenesis: Role and regulation of mixed-function oxidases and related enzymes. Physiol. Rev. 1980, 60, 1107-1166. [CrossRef] [PubMed]

33. Schoket, B.; Papp, G.; Lévay, K.; Mracková, G.; Kadlubar, F.F.; Vincze, I. Impact of metabolic genotypes on levels of biomarkers of genotoxic exposure. Mutat. Res. 2001, 482, 57-69. [CrossRef]

34. Lee, B.M.; Shim, G.A. Dietary exposure estimation of benzo[a]pyrene and cancer risk assessment. J. Toxicol. Environ. Health A 2007, 70, 1391-1394. [CrossRef]

35. Kwack, S.J.; Lee, B.M. Correlation between DNA or protein adducts and benzo[a]pyrene diol epoxide I-triglyceride adduct detected in vitro and in vivo. Carcinogenesis 2000, 21, 629-632. [CrossRef]

36. Halappanavar, S.; Wu, D.; Williams, A.; Kuo, B.; Godschalk, R.W.; Van Schooten, F.J.; Yauk, C.L. Pulmonary gene and microRNA expression changes in mice exposed to benzo(a)pyrene by oral gavage. Toxicology 2011, 285, 133-141. [CrossRef]

37. Penning, T.M.; Ohnishi, S.T.; Ohnishi, T.; Harvey, R.G. Generation of reactive oxygen species during the enzymatic oxidation of polycyclic aromatic hydrocarbon trans-dihydrodiols catalyzed by dihydrodiol dehydrogenase. Chem. Res. Toxicol. 1996, 9, 84-92. [CrossRef] 
38. Buening, M.K.; Wislocki, P.G.; Levin, W.; Yagi, H.; Thakker, D.R.; Akagi, H.; Koreeda, M.; Jerina, D.M.; Conney, A.H. Tumorigenicity of the optical enantiomers of the diastereomeric benzo[a]pyrene 7, 8-diol-9, 10-epoxides in newborn mice: Exceptional activity of (+)-7 $\beta, 8 \alpha$-dihydroxy-9 $\alpha, 10 \alpha$-epoxy-7, 8, 9, 10-tetrahydrobenzo[a]pyrene. Proc. Natl. Acad. Sci. USA 1978, 75, 5358-5361. [CrossRef]

39. Slaga, T.J.; Bracken, W.J.; Gleason, G.; Levin, W.; Yagi, H.; Jerina, D.M.; Conney, A.H. Marked differences in the skin tumor-initiating activities of the optical enantiomers of the diastereomeric benzo(a)pyrene 7 , 8-diol-9, 10-epoxides. Cancer Res. 1979, 39, 67-71.

40. Kasai, H.; Nishimura, S.; Kurokawa, Y.; Hayashi, Y. Oral administration of the renal carcinogen, potassium bromate, specifically produces 8-hydroxydeoxyguanosine in rat target organ DNA. Carcinogenesis 1987, 8, 1959-1961. [CrossRef]

41. Hakura, A.; Tsutsui, Y.; Sonoda, J.; Kai, J.; Imade, T.; Shimada, M.; Sugihara, Y.; Mikami, T. Comparison between in vivo mutagenicity and carcinogenicity in multiple organs by benzo[a]pyrene in the lacZ transgenic mouse (Muta Mouse). Mutat. Res. 1998, 398, 123-130. [CrossRef]

42. Sehgal, A.; Kumar, M.; Jain, M.; Dhawan, D.K. Modulatory effects of curcumin in conjunction with piperine on benzo(a)pyrene-mediated DNA adducts and biotransformation enzymes. Nutr. Cancer 2013, 65, 885-890. [CrossRef] [PubMed]

43. Zhu, W.; Cromie, M.M.; Cai, Q.; Lv, T.; Singh, K.; Gao, W. Curcumin and vitamin E protect against adverse effects of benzo[a]pyrene in lung epithelial cells. PLoS ONE 2014, 9, e92992. [CrossRef] [PubMed]

44. Revel, A.; Raanani, H.; Younglai, E.; Xu, J.; Han, R.; Savouret, J.F.; Casper, R.F. Resveratrol, a natural aryl hydrocarbon receptor antagonist, protects sperm from DNA damage and apoptosis caused by benzo(a) pyrene. Reprod. Toxicol. 2001, 15, 479-486. [CrossRef]

45. Mohamed, E.-S.A.; Song, W.H.; Oh, S.A.; Park, Y.J.; You, Y.A.; Lee, S.; Choi, J.Y.; Kim, Y.J.; Jo, I.; Pang, M.G. The transgenerational impact of benzo(a)pyrene on murine male fertility. Hum. Reprod. 2010, 25, 2427-2433. [CrossRef]

46. Shi, Z.; Dragin, N.; Galvez-Peralta, M.; Jorge-Nebert, L.F.; Miller, M.L.; Wang, B.; Nebert, D.W. Organ-specific roles of CYP1A1 during detoxication of dietary benzo[a]pyrene. Mol. Pharmacol. 2010, 78, 46-57. [CrossRef]

47. Cai, Y.; Lv, J.; Zhang, W.; Zhang, L. Dietary exposure estimates of 16 polycyclic aromatic hydrocarbons (PAHs) in Xuanwei and Fuyuan, counties in a high lung cancer incidence area in China. J. Environ. Monit. 2012, 14, 886-892. [CrossRef]

48. Martorell, I.; Nieto, A.; Nadal, M.; Perelló, G.; Marcé, R.M.; Domingo, J.L. Human exposure to polycyclic aromatic hydrocarbons (PAHs) using data from a duplicate diet study in Catalonia, Spain. Food Chem. Toxicol. 2012, 50, 4103-4108. [CrossRef]

(C) 2019 by the authors. Licensee MDPI, Basel, Switzerland. This article is an open access article distributed under the terms and conditions of the Creative Commons Attribution (CC BY) license (http://creativecommons.org/licenses/by/4.0/). 